I. Tchaikovsky. K.: NMAU after P. I. Tchaikovsky,. issue 105. On musical history tables: Ukrainian music and cultural process. In honor of Marianne Davydovna Copy. Pp. 154-165 [in Ukrainian].

16. Pyaskovsky, I.(1987) Logic of Musical Thinking. Kiev: Muzychna Ukraine, [in Russian].

17. Trembovelsky, E. (2010). Style of Mussorgsky. Harmony, harmony, warehouse. M.: OOO Publishing House «Composer», [in Russian].

18. Tyshko, S. (1993). The problem of national style in the Russian opera. Glinka, Mussorgsky, Rimsky-Korsakov. K.: EP «Muzinform» [in Russian].

19. Kholopova, V. (1994). Music as a form of art. Moscow: Scientific and Creative Center «Conservatory», 1994. [in Russian].

20. Khubov, G. (1969). Mussorgsky. M.: Music [in Russian].

21. Cherednichenko, T. (1982) Aesthetics musical. The musical encyclopedia. In 6 vols. M: Sovetskaya encyclopedia, 1982. - Vol 6. URL: http://enc-dic.com/ enc_music/JEstetika-Muzykalnaja-8406.html [in Russian].

22.Burmeister, J, and Benito V. Rivera (1993). Musical Poetics. Yale University Press, JSTOR, URL: www.jstor.org/stable/j.ctt32bsq9. [in English].

23.Poetics of Music. (2015) The Project. Kings College. London, 2015. URL: https://www.kcl.ac.uk/artshums/depts/music/research/proj/poetics/index.aspx [in English].

24.Stravinsky, I,. \& Knodel, A., Dahl, I. (1947). Poetics of Music in the Form of Six Lessons. Translators:. New York: Vintage Books, [in English].

25.The New Grove Dictionary of Music and Musicians. In 20 volumes. Ed. by S. Sadie. London, 1972-1980. [in English].

Стаття надійцла до редакції 12.04.2017

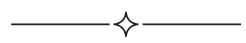

УДК 78.071.1:781.62(44)«17»

\title{
Лю Бинь
}

аспирант кафедры теории музыки и фортепиано

Харьковской государственной академии культуры

odma_n@ukr.net

\section{КРЕЩЕНДИРОВАНИЕ ОБРАЗОВ АДА КАК МЕТОД ИНТОНАЦИОННОЙ ДРАМАТУРГИИ ОПЕРЫ А. САЛЬЕРИ «ДАНАИДЫ»}

Цель исследования - раскрыть сущность крещендирования образов ада как метода интонационной драматургии в опере А. Сальери «Данаиды». Научная новизна исследования обусловлена тем, что в нем впервые 
представлен анализ смыслообразующей роли интонем, репрезентирующих образ ада; изучена роль крещендирования как метода воплощения сквозной драматургии в опере А. Сальери «Данаиды». Методология исследования заключается в применении семантического подхода к рассматриваемой проблематике, в сочетании с компаративным и текстологическими методами. Выводы. Выявлено своеобразие интонационной драматургии опреного творчества А. Сальери на примере анализа одного из его шедевров, развивающего традиции жанра франиузской лирической трагедии. В основе творческого метода композитора в опере «Данаиды» - крещендирование семантики образов ада, формирующихся, начиная с 1 картины. Анализ показал, что избранный А. Сальери подход свидетельствует, что в рассматриваемой опере воплощены передовые для эпохи Просвещения глюковские идеи, предвосхищены новации оперного искусства будущего (в частности лейтмотивный метод).

Ключевые слова: "Данаиды», А. Сальери, интонема, крещендирование, драматургия оперы.

Liu Bin, graduate student of the of the Theory of music and piano department of The Kharkiv State Academy of Culture

Creschendo of images of hell as a method of intonation dramatic opera «Danaides» by A. Salieri

The purpose of research is to discover the essence of creschending of hell images as a method of intonation drama in opera A. Saleri «Danaides». Scientific novelty of research is due to the fact that for the first time it presents an analysis of the sense-making role of the intonems which represent the hell image; role of creschending as a method of realization through drama in the opera of «Danaides» by Salieri. The methodology of the research consists in applying a semantic approach to the problematic, in combination with comparative and textual methods. Conclusions. The originality of intonation drama of opera creativity of $A$. Salieri is revealed based on the example of the analysis of one of his masterpieces, developing traditions of the genre of the French lyric tragedy. The foundation of the creative composer's method of "Danaides» opera is creschending of semantics of hell images formed from the 1st picture. The analysis showed that the A. Salieri's chosen approach shows that this opera embodies leading Gluck's ideas in the Enlightenment, the innovations of the opera future is anticipated (in particular leitmotif technique).

Keywords: «Danaides» A. Saleri, intonem, creschending, opera drama.

Лю Бінь, аспірант кафедри теорії музики і фортепіано Харківської державной академії культури

Крещендування образів пекла як метод інтонаційної драматургії опери А. Сальєрі «Данаїди»

Мета дослідження - розкрити сутність крещендування образів пекла як методу інтонаційної драматургії в опері А. Сальєрі «Данаїди». 
Наукова новизна дослідження зумовлена тим, що в ньому уперше запропоновано аналіз смислоутврюючої ролі інтонем, що репрезентують одраз пекла, вивчена роль крещендування як методу втілення наскрізної драматургії в опері А. Сальєрі «Данаїди». Методологія дослідження полягає у застосуванні семантичного підходу до розглянутої проблематики, у поєднанні з компаративними та текстологічним методами. Висновки. Виявлено своєрідність інтонаційної драматургії оперної творчості А. Сальєрі на прикладі аналізу одного з його шедеврів, який розвиває традиціі жанра франиузької ліричної трагедії. В основі творчого методу композитора в опері «Данаїди» - крещендування семантики музично-поетичних образів пекла, що формуються, починаючи з 1 картини. Аналіз доводить, що обраний A. Сальєрі підхід свідчить, що у розглянутій опері втілено передові для епохи Просвітництва глюківські ідеї, передбачено новації оперного мистецтва майбутнього (зокрема лейтмотивний метод).

Ключові слова: "Данаїди», А. Сальєрі, інтонема, крещендування, драматургія опери.

Актуальность темы исследования. Опера «Данаиды» («Danaïdes», 1784, Париж, жанр - французская лирическая трагедия в 5 актах, либретто Лебланка дю Руле и Барона Чуди, адаптировавших сочинение Раньеро де Кальцабиджи) - один из шедевров в наследии Антонио Сальери. Анализ показал, что А. Сальери не только воплотил здесь те наиболее прогрессивные трактовки жанра, что сформировались к этому времени в творчестве К. В. Глюка, чья карьера к этому времени была завершена, и В. А. Моцарта, стремительного восходящего к вершинам оперного олимпа, но и предвосхитил новации оперы будущего. А. Сальери, как, впрочем, и В. А. Моцарт в 80-е годы XVIII столетия, наследовал идеи глюковской реформы. Однако выступил не столько в роли скромного подражателя, сколько, творчески преломив новаторские достижения предшественника, раскрыл и собственную художественную индивидуальность. Один из своеобразных методов оперной драматургии, в полной мере демонстрирующий самобытность композиторского дарования А. Сальери, следует определить как крещендирование интонационной символики от сцены к сцене, достигающей кульминации в Финале. Метод крещендирования в «Данаидах» А. Сальери предстает как своеобразное претворение метода сквозной драматургии - новаторского для оперы последней четверти XVIII века. Крещендирование как метод интонационной драматургии «Данаид» проявляется в связи с поэтапным развертыванием семантики образов ада и итоговым «отстранением» прочих значимых интонационных символов из интонационного фонда Финала, 
изображающего адские муки грешников. Выявление своеобразия оперной драматургии А. Сальери, нашедшего отражение в «Данаидах», в частности в методе крещендирования интонационной идеи, представляется актуальной задачей современной музыковедения, поскольку способствует пересмотру исторической и художественной роли несправедливо исключенного из процесса развития музыкального искусства композитора.

Цель исследования - раскрыть сущность крещендирования образов ада как метода интонационной драматургии в опере А. Сальери «Данаиды».

Задачи исследования:

- изучить интонационную драматургию оперы А. Сальери «Данаиды»;

- определить специфику сквозной драматургии оперы;

- выявить семантику интонем, имеющих отношение к формированию смыслообразов ада в драматургии оперы;

Объект исследования - интонационная драматургия оперы А. Сальери «Данаиды».

Предмет исследования - крещендирование как метод интонационной драматургии оперы А. Сальери «Данаиды».

Научная новизна исследования обусловлена тем, что в нем впервые представлен анализ смыслообразующей роли интонем, репрезентирующих образ ада; изучена роль крещендирования как метода воплощения сквозной драматургии в опере А. Сальери «Данаиды».

Одним из новаторских аспектов оперы является сквозное развитие образов ада, которые находят своё кульминационное воплощение в Финале, что позволило определить данный метод драматургии как принцип крещендирования.

В заключительной XI сцене 5 действия непосредственно перед взором зрителей (как следует из ремарки авторов либретто и оперы) происходит смена декораций. Сцена являет собой «подземный мир. Виден Тартар с катящимися волнами крови по краям и в середине театра, Данай, прикованный к скале; его окровавленные внутренности поедают стервятники, его голова поражена ударом молнии. Данаиды, соединенные друг с другом в группы, терзаемы демонами и поедаемы змеями. Другие, преследуемые яростью, заполняют театр своими движениями и криками». Только лишь содержание ремарки свидетельствует о том, что А. Сальери в Финале оперы создал столь масштабную картину Ада, не лишенную натуралистических черт, ко- 
торая не имела аналогов в истории оперы в творчестве его великих предшественников, в числе которых - и К. В. Глюк. Великий оперный реформатор не изображал адские муки грешников, предпочитая воспроизводить устрашающий «адский пейзаж» и источающих ужас обитателей Inferno. Вместо этого А. Сальери, наряду с «пейзажной» обрисовкой Ада, отображает муки грешников, казнимых за свершенные при жизни прегрешения. В Финале оперы А. Сальери представлена картина Божьего гнева («дрожит земля, грохочет небо» - слова из партии Линкея и хора, сцена XI) и страдания грешников, достигающие поистине дантовского размаха.

Сцена Inferno трактована композитором как Финал, основанный на взаимодействии тех интонаций-символов, что формировались на протяжении всей оперы, чьи функции и значение постепенно выкристаллизовывались в зависимости от взаимосвязанных с ними сценических ситуаций и ключевых слов, что способствовали конкретизации их содержания.

Опера в целом представляет собой своего рода «путь в Ад», поскольку в интонационную драматургию исподволь вводятся те интонемы, инфернальное предназначение которых со всей полнотой и определенностью раскроется в финальной сцене как воплощение адских мук грешников, низвергнутых за содеянные злодеяния в Тартар. Примененный композитором метод интонационного опережения, связанный с введением в музыкальную драматургию смыслообразов инфернального содержания, предваряющих их сценически-вербальное воплощение, свидетельствует о сотворении в опере собственно музыкального образа Ада. Интонационные прообразы Тартара, музыкально-сценическая картина которого представлена в Финале, формируются, начиная с I сцены 1 действия. Второй раздел всеобщей клятвы непорочности и мира, быть свидетельницей которой призвана Юнона, содержит лаконичную картину «ужасного наказания», которое должно постигнуть клятвопреступников. На их головы падет удар «божественной молнии», обрушится ярость богов Стикса, постигнет чудовищная судьба, сердце наполнится «змеями ада». Обрамленный идеальными сценами мира и любви, второй раздел 1 сцены представляет собой прообраз, пророчество грядущего возмездия, воздаяния, той картины Ада, что в развернутом виде будет явлена в Финале оперы. Картины «счастливого дня» (представлены в I части Alegro vivace и в III части Maestoso) контрастируют «Дню гнева» (II часть), воссоздающего видение грядущих адских мук клятвопре- 
ступников. В интонационной драматургии «Дня гнева» доминируют речитации на одном звуке, символизирующие образ рока, тремоло в оркестре, воспроизводящее образ душевного трепета героев, подвергнутых божественному воздаянию, ходы по звукам уменьшенных гармоний, символизирующие «ужасное» в музыке, тираты в оркестровой партии символизируют образы ярости, наполняющие сердца клятвопреступников.

В масштабах I сцены 1 действия важное значение, с точки зрения формирования Финальной картины адских мук клятвопреступников, имеет кода. В разгар утверждения культа наслаждения, сопровождающего картину гедонизма, сформированную в воображении героев, благодаря надежде на утверждение идеалов любви и дружбы, появляется первое в опере упоминание о внезапной смерти, ударе судьбы, подстерегающем любого из героев действия: «без шума зачастую проскальзывает смерть»; «в любой момент роковая лодка может увезти без возврата». В коде происходит возвращение в интонационную драматургию речитаций на одном звуке, что позволяет сделать вывод о том, что композитор на данном этапе развития музыкальной драматургии идентифицирует образы рока и смерти, связывая их посредством общей интонемы. В оперную партитуру на данном этапе развития интонационной драматургии возвращаются интонемы душевного трепета (тремоло в оркестре) и интонема ярости. Кода I сцены 1 действия по своей сути представляет собой пророчество внезапной, непредсказуемой смерти, дважды вторгающейся в развитие заключительного 5 действия оперы (коварное убийство сыновей Египта; Божественная кара, постигшая клятвопреступников - Даная и его дочерей). Значение коды I сцены 1 действия в опере А. Сальери, помимо провозглашения идеи внезапности неожиданной смерти, состоит также и в том, что в ней установлено местоположение картины адских мук, трактованной как завершающий, финальный этап в развитии действия.

Каждый новый смысловой этап в развитии оперного действия в I сцене 1 акта связан с обращением, воззванием героев к тому или иному Богу или Богине, покровительствующим определенному роду занятий. Так, в 1 действии сменяющие друг друга на соответствующих этапах развития действия воззвания к Юноне, Гименею, Бахусу завершаются призывом, обращенным к четвёртой богине - Парке, являющейся олицетворением судьбы. Развитие интонационной драматургии в коде I сцены 1 действия дает основание предполагать, что 
интонема рока эквивалентна интонеме Парки как персонификации судьбы. Подобная логика развития интонационной драматургии позволяет прийти к выводу о всеприсутствии неназванного (вплоть до коды) образа Парки на всех этапах развития действия I сцены 1 акта (клятва, возмездие, бракосочетание).

I сцена заканчивается роковым предвестьем кровавой развязки, которую никто из персонажей оперы, кроме коварного Даная, не мог предполагать. Для интонационной драматургии оперы А. Сальери характерно взаимодействие двух планов течения действия: его реального, очевидного становления и основанного на череде предзнаменований предчувствия тайной, трагической развязки.

Значение I сцены 1 действия в развертывании концепции ФиналаInferno в опере А. Сальери заключается в формировании интонационного прообраза финальной картины адских мук (2 раздел I сцены); в утверждении идеи внезапной смерти и ее местоположения в контексте целого, то есть в заключительном разделе развития действия (кода I сцены).

Таким образом, в I сцене 1 действия сформирован прообраз дальнейшего оперного действия, претерпевающего развитие от идеального к трагическому (ужасному), преображающегося от клятвы дружбы и любви к возмездию. В результате I сцена 1 действия обладает функцией пролога, предопределяющего развитие оперного действия.

Сцену II открывает любовный диалог Линкея и Гипермнестры. Тема любовных уз омрачена страхом, предчувствиями обмана, угрозы, обманчивости счастья (отголоски темы рока в партии Линкея). Взаимодействие образов надежды на счастье и рокового предзнаменования привносит двойственность в развитие действия: разум уповает на счастье, сердце предчувствует беду («Боги, неужели вы будете так жестоки, что лишите нас нашего счастья», - реплика Гипермнестры). Внутренняя (любовная) драма Линкея и Гипермнестры также подчинена развертыванию образов ада, кульминация которых связана с Финалом оперы.

I сцена 2 действия (Данай ведёт своих дочерей в подземный храм Немезиды - богини мщения) контрастна 1 акту. Гимн Гименею сменяется поклонением Немезиде; день - ночью. Гармония мужского и женского начал утрачена: символом грядущего клятвопреступления и мести является доминирование женской вакханалии - символа неправедного возмездия. Интонационные символы рока «сгущаются». Подобно тому, как божественной персонификацией любви являет- 
ся Гименей, так воплощением возмездия/рока становится Немезида. Контраст углубляет столкновение смыслообразов любви и рока, мужского и женского начал, Гименея и Немезиды. Показательно, что в опере А. Сальери с мужским началом связаны мягкие, лирические интонации, тогда как с женским «миром» - мелодические обороты, обладающие воинственной, роковой символикой.

В оркестровую партию I картины 2 действия проникают новые интонационные символы inferno: интонемы фурии, темы адских вихрей (стремительные пассажи в оркестре), уменьшенные гармонии как знаки «ужасного» («мертвенные» аккорды-педали), оркестровое тремоло (воплощение душевного волнения героев, которое в Финале станет означать дрожь земной тверди, словно бы «расступающейся» под ногами грешников и поглощающей их). Роковые речитации на одном звуке в оркестровой и вокальной (речитатив-secco - символ застывшей смерти) партиях обретают более напряженное развитие. А. Сальери перенимает реформаторский опыт К. В. Глюка в музыкальном отображении ужасного и смертоносного, трактуя его многомерно, основываясь на множестве интонаций-символов.

Помимо символов рока I картину 2 действие отличает напряженная атмосфера тайны, под покровом которой происходит развертывание сцены заговора, мести, новой преступной клятвы Немезиде, данной Данаем и его дочерьми.

Важную роль в формировании образов ада играет рассказ-монолог Даная о предыстории событий (І сцена 2 действия). Помешённый в начало 2 действия 5-актной оперы, он позволяет соотнести драматургию А. Сальери не только с новаторским прошлым в истории жанpa, но и с оперой будущего - романтическими драмами Р. Вагнера (рассказы Лоэнгрина, Тангейзера), Дж. Верди (рассказы Феррандо, Азучены из оперы «Трубадур»).

Рассказ Даная «вписан» в музыкальную драматургию I сцены 2 действия оперы, не являя собой самостоятельный «номер». Композиторская трактовка рассказа позволяет сделать вывод о роли сквозной драматургии в опере А. Сальери. Рассказ Даная (сопровожден тремоло в оркестре, символизирующим душевную тревогу, трепет, рок) прерывают реплики хора (дочерей преступного отца), что также способствует приданию черт сквозной драматургии сольному высказыванию.

Хоровая клятва отмщения в Es dur, основанная на сигнальной семантике, исполнена предчувствием «бетховенской» героики. Символы ужасного продолжают свое развитие в арии мести Даная (d moll). 
Взаимодействие музыкальных символов - ярости, адских вихрей (в партиях скрипок и альтов), сигнальных интонаций клятвы (у фаготов), торжественных октавных ходов (в вокальной партии) - позволяют трактовать сольное высказывание Даная как арию мести - один из этапов крещендирования образов ада в опере. Продолжением арии мести является хор мести дочерей преступного царя, основанный на развитии музыкальной семантики отмщения. Драма мести на данном этапе развертывания действия достигает кульминации в финальных тактах I сцены 2 акта.

II сцена 2 действия представляет собой диалог непонимания, разворачивающийся между Гипермнестрой - носительницей идеи любви, самопожертвования, сострадания и Данаем - воплощением идеи мести. Важную роль в развитии драмы непонимания играют музыкальные символы ужаса Гипермнестры и гнева Даная. Столкновение (поединок) мировоззрений, драма идей, конфликт мщения и любви позволяют трактовать диалог как перелом в развитии внутренней драмы. В ее оформлении роль оркестра минимизирована вплоть до реплики Гипермнестры, призывающей небо в свидетели первоначальной клятвы любви и верности: пробуждение оркестра, усиливающего содержание вербального текста, связано со словом «небо» в партии героини. Значение реплики Гипермнестры в формировании драмы многомерно: небо, боги и сам композитор на стороне героини, исповедующей идею любви.

В завершающем II сцену 2 акта лжепророчестве Даная в оркестре символически изображён полёт смерти на словах: «над вами обоими пролетит смерть», интонационным прообразом которой следует считать тему адских вихрей, впервые возникающую в сцене клятвы Немезиды.

Bo II сцене 2 действия очевидно следование А. Сальери новаторскому принципу музыкальной драматургии опер К. В. Глюка: музыка способствует развитию драмы, усиливая ее значение. В сцене духовного поединка Гипермнестры и Даная, поединка мести и любви слово выводится на первый план. Альтернатива в понимании идеи долга как мщения (Данай) и как любви (Гипрмнестра) - сопряжена с раскрытием глюковской темы самопожертвования.

B I сцене 3 действия (хоровая сцена «Пусть Аврора придёт не так быстро») композитор подчёркивает значимость образа ночи. Тема судьбы вводится в виде контрапункта музыкальному образу восходящей Авроры. В развёрнутую хоровую сцену, связанную с прослав- 
лением любви, введен важнейший мотив, обусловленный процессом крещендирования образов ада: кубок вина в глазах Гипермнестры, предчувствующей ужасную развязку, словно бы наполняется кровью. На гребне высшего торжества, в кульминационной зоне (Линкей передаёт невесте кубок) в партии оркестра происходит развитие интонемы адских вихрей, символизирующих образ Немезиды, превращение вина в кровь, чаши любви - в чашу смерти. Завершающий I сцены 3 действия драматургический слом (сцена ужаса Гиперместры) связан с трансформацией диалога согласия в диалог непонимания (Линкей изумлен реакцией Гипермнестры). Показательно, что драматургический слом возникает внутри сцены, придавая ей черты сквозного развития. Слово «ужас» становится ключевым в партии Гипермнестры. Героине присущ «комплекс Кассандры» (предчувствуя, она не может предотвратить свершение ужасной развязки; видя кровь в кубке вина, героиня предвидит реки крови, изливающиеся на грешную землю).

Сама структура сцены, связанная с кульминацией ужасного в ее завершении, предваряет конструкцию всей оперы, основанной на крещендировании образов ада в Финале. Пророчество кровавой развязки сформировано здесь на различных уровнях развития оперного действия: сюжетном (сцена ужасного пророческого видения героини) и драматургическом.

4 действие во многом обретает функцию репризы первоначальных этапов развития роковой драмы. Образы слёз, клятвы, рока, мести, самопожертвования во имя любви, предчувствия смерти - свидетельства концентрации ключевых идей оперы, возводящих драматургическое развитие оперы к некоему «пику», после которого неминуема трагическая развязка. Формирование оппозиции идей преступления и искупления свидетельствует о новом этапе в развитии драмы мести и любви. Духовный поединок Даная и Гипермнестры знаменует кульминацию в ее развитии: отец отвергает мольбы дочери о помиловании, тем самым сообщая качество предопределенности трагической развязке.

IV Сцена 4 акта являет собой смерть женихов-братьев, безжалостно убиенных коварными дочерьми Даная. Вопреки закону античной драматургии, основанному на запрете показа ужасного события на сцене, композитор-драматург рискует развернуть ужасную сцену гибели сыновей Египта перед глазами Гипермнестры и, следовательно, зрителей. Лейтмотивы рока-смерти, яростного мщения, адских вихрей играют здесь доминирующую роль, как бы свидетельствуя о воца- 
рении ада на земле. Новаторство Сальери проявляется и в отсутствии антракта между 4 и 5 актами (сохранены те же декорации), что является еще одним свидетельством значимости сквозного действия в опере, подчеркнутого важностью одного из трех единств классицистского театра - единства места.

Музыкальный хронотоп 5 действия предельно семантизирован: убранство сцены напоминает начало второй реформаторской оперы К. В. Глюка «Альцеста» (героиня приходит в царство теней, чтобы принести себя в жертву вместо своего мужа). Ассоциация усиливается и тем, что изложение темы адских вихрей прерывают сумрачные аккорды, символизирующие застылость смерти.

Если первой половине 5 действия свойственна камерность (ария, сольная и диалогическая сцены), то его финальные сцены (начиная c IV) отличает монументальность. Гимн Бахусу представляет окровавленных Данаид, опьяненных местью, превратившихся в вакханок, впадающих в безумие. Бога охоты - Ситера - прославляют свирепые сёстры Гипермнестры, истребившие своих мужей. Важную роль в музыкальной драматургии оперы играет введенная в IV сцену интонема судьбы в виде музыкального символа, предваряющего его бетховенскую трактовку.

Непосредственно предваряет Финал сцена торжества Даная, обращающегося к своим преданным дочерям с требованием настичь и покарать избегнувшего мести Линкея, и обличающего отступницу Гипермнестру. Для Даная его верные дочери по-прежнему предстают как орудие мести (воззвание отца «И завершите мою месть» на фоне темы рока как аналога мести).

Функцию финала выполняет XI сцена 5 действия, являющая собой музыкально-сценическую картину ада. Здесь представлены муки грешников - Данаид под предводительством преступного отца, истязаемых в Тартаре. Пассажи ярости, аккорды рока, змеевидная тема адских вихрей, тема трепета способствуют раскрытию идеи возмездия. Финальная сцена, обретя функцию кульминации оперы, воспроизводит идею неотвратимой расплаты за совершённое преступление, будучи раскрытой здесь, как отмечает М. Мугинштейн, «с устрашающим величием» $[3,183]$.

Выводы. В опере А. Сальери «Данаиды» раскрытие темы финальных адских мук грешников сопряжено с процессом психологизации образов, воплощающих тему злодеяния, клятвопреступления. Принято считать, что психологизация образов отрицательных персона- 
жей (оперных злодеев) в оперном искусстве связана только лишь с XIX столетием, когда вызревают условия для музыкальной характеристики таких противоречивых персонажей, как, например, Яго, Мефистофель. Однако в опере А. Сальери «Данаиды» образ преступного царя Даная раскрыт в единстве образующих его противоречий, обуревающих героя скрытых страстей. Композитор не только представляет мотивировку побуждений мстительного царя, но и прибегает к приему своего рода полифонической в своей основе обрисовки героя, внешне руководствующегося идеями прощения и дружбы (сцены клятвы, бракосочетания), на самом же деле движимого задачей осуществления заранее спланированной мести, организации кровавого преступления.

Наряду с портретными характеристиками Даная А. Сальери прибегает к такому методу музыкальной драматургии, как интонационное оформление тем-идей, символизирующих высшее (посмертное) возмездие - рока, ярости, адских вихрей. Их оформление характеризуется постепенностью вызревания, поэтапным крещендированием и подлинным «взрывом» в Финале оперы.

Исходя из вышеотмеченного, следует сделать вывод о том, что А. Сальери должен быть отнесен к числу выдающихся композиторовдраматургов в истории оперного искусства.

\section{СПИСОК ЛИТЕРАТУРЫ}

1. Кириллина Л. Реформаторские оперы Глюка.М.: Классика-XXI, 2006. $384 \mathrm{c}$.

2. Кириллина Л. Пасынок истории (К 250-летию со дня рождения Антонио Сальери). Музыкальная академия. 2000. № 3. С. 57-73.

3. Мугинштейн М. Хроника мировой оперы. Екатеринбург : У-Фактория, 2005. T. $1.640 \mathrm{c}$.

4. Einstein A. Gluck : Sein Leben - seine Werke. Zürich; Stuttgart : Pan-Verlag, 1954. $315 \mathrm{~s}$.

5. Rice J. A. Antonio Salieri and viennese opera. Chicago : University of Chicago Press, 1998. 650 p.

\section{REFERENCES}

1. Kirillina, L. (2006). Reformer operas of Gluk. M.: Classics - XXI [in Russian].

2. Kirillina, L. (2000). The stepson of history (on the 250th anniversary of the birth of Antonio Salieri). Musical Academy. № 3. p. 57-73 [in Russian].

3. Mouginshtein, M.(2005) Chronicle of the world opera. Ekaterinburg: U-Factoria, Vol. 1. [in Russian]. 
4. Einstein, A.(1954). Gluck : Sein Leben - seine Werke. Zbrich. Stuttgart : Pan-Verlag [in German].

5. Rice J. A. (1998), Antonio Salieri and viennese opera. Chicago : University of Chicago Press [in English].

Стаття надійшла до редакції 05.04.2017

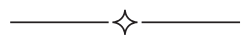

УДК 78.03.78

\author{
Ван Минизе \\ соискатель Одесской национальной музыкальной \\ академии имени А. В. Неждановой \\ odma_n@ukr.net

\section{ЛИРИЧЕСКИЙ ГЕНЕЗИС МУЗЫКИ И НАД-, ВНЕИНДИВИДУАЛЬНЫЕ ФОРМЫ ЕГО ПРОЯВЛЕНИЯ В ХРАМОВОМ ГИМНОПЕНИИ КИТАЯ И ЕВРОПЫ}

Цель работы. Исследование связано с поиском лирического принципа выражения по его генезису и развитию в культовом гимнопении. Недооценка религиозных истоков искусства в музыкальной сфере чревата потерей ориентиров на идеальную специфику этого вида творчества, что в условиях современной экспансии шоу-бизнеса затрудняет сохранность этого рода художественного достояния. Методология исследования определяется опорой на интонационное видение специфики музыки, ито вводит стилевой компаратив и историко-логический методы в качестве базовых, позволяя выявить смысловую парадигматику музыки, заложенную ее ритуально-религиозным истоком. Научная новизна состоит в расширении представлений о лирике как обусловливаемой вне- и надличностным характером выразительности храмового пения. Сравнительный анализ храмовой лирики в Китае и в Европе выводит на универсально-человеческие принципы музыкальной выразительности, черпающие в культе истоки высокой абстракции ее символики и экстатики. Выводы. В гимнопении происходит формирование лирической полноты возвышения над бытийностью - в пении как преодолении речевой ограниченности диапазона, как гипертрофии круговых движений голоса в виде фигуративных построений, как способ запечатления высокого без-волия, противостоящего моделям волевых устремлений, которые имеют место в музыке, выстроенной в гармонической вводнотонности.

Ключевые слова: лирический генезис, лирика, гимнопение, храмовость. 